\title{
Capital flows in Montenegro: SVAR model ${ }^{* 1}$
}

\author{
Milena Lipovina-Božović ${ }^{2}$, Maja Ivanović ${ }^{3}$
}

\begin{abstract}
Analysing push and pull determinants of capital flows has become increasingly important with global financial crisis. Namely, global financial crisis has shown that large and volatile capital flows can pose risks, especially, for small and open economies. In this paper we are particularly interested to analyse the vulnerability of capital flows in country with limited monetary policy. We are focused on Montenegro, the country that unilaterally adopted euro in 2002 and regained independence in 2006. Since then, Montenegro has become very attractive for investments and has received significant amounts of foreign capital. Thus, in this paper we are assessing how global shocks could be dangerous for such a small open economy. In addition, we are interested in investigating whether domestic factors can influence capital flows due to the full euroization. In order to answer these questions, we have applied structural vector autoregressive model of the determinants of two main components of capital flows, foreign direct investments and portfolio investments separately, using quarterly data from 2005 to 2017. We provide evidence that mainly push factors, such as foreign output, interest rates and euro area risk sentiment, significantly explain the variation of capital flows. Furthermore, domestic factors are found to play little role for capital flow developments in Montenegro.
\end{abstract}

Key words: capital flows, push and pull factors, SVAR, foreign direct and portfolio investments, Montenegro

JEL classification: $C 32, F 21, F 32$

* Received: 23-03-2018; accepted: 06-12-2018

1 The findings, interpretation and conclusion expressed in the Article are those of the authors and should not be attributed to the Faculty of Economics, University of Montenegro and Central bank of Montenegro.

2 PhD in Economics, Teaching assistant, University of Montenegro, Faculty of Economics, Jovana Tomaševića 37, 81000 Podgorica, Montenegro. Scientific affiliation: macroeconomics, applied econometrics, economic statistics and mathematical models. Phone: +382 20241138. Fax:+382 20244 588. E-mail: milena@ac.me (corresponding author).

$3 \mathrm{PhD}$ in Economics, Special advisor to director of department for financial stability, research and statistics, Central bank of Montenegro, Bulevar Sv. Petra Cetinjskog br. 6, 81000 Podgorica, Montenegro. Scientific affiliation: macro and monetary economics and applied econometrics. Phone: +382 20403 221.E-mail:maja.ivanovic@cbcg.me. 


\section{Introduction}

Montenegro is a small open economy which has no controls on capital mobility. During the past twelve years, and particularly since it regained its independence, Montenegro has achieved major progress measured in increase of the Gross domestic product (GDP). The accelerated economic growth meant higher capital inflows, especially foreign domestic investments (FDIs). Montenegro attracted the largest FDI inflows / per capita in Europe. In terms of the share of FDIs in gross domestic product, Montenegro has been a leader in the group of European economies in transition in the pre-crisis period (IMF, 2008).

The increase in foreign capital inflows in Montenegro was, to a large extent, considered as a natural part of Montenegrin catching-up process with the euro area. Montenegro did not have sufficient sources of accumulations; therefore, it was largely oriented towards the inflow of foreign accumulation (Fabris, et al., 2008). Furthermore, Montenegro faced a steep convergence path to average European income levels, associated with large capital inflows and strong credit growth (IMF, 2008). Independence has induced intense external interest, and large capital flows have been directed towards investments in banking sector, real estate, telecommunications, and in the recovering tourism sector.

The prospect of accession to the European Union fostered a rapid integration with EU financial market, including a substantial presence of foreign-owned banks. The credit surge was facilitated by foreign financial institutions entering to Montenegrin market with the objective of rapidly increasing their market share. Furthermore, high inflow of FDI had significant impact on the growth of deposits and thus on the development of the banking system, as well as the capital market. Impact on the growth of deposits was two-sided. On one hand, as the result of sale of property and real estate, part of the money was deposited in the banking system in the form of deposits. On the other hand, through the process of foreign investments, credible foreign companies have arrived on the Montenegrin market and became important clients of the banking system.

Country`s euroisation probably offered foreign investors a form of insurance against potential devaluation, and was merited for large capital inflows. Other factors which might have contributed to those high capital inflows included low taxes, free trade regime and transfer of capital and reductions in other barriers to business. However, even though euroization contributes to the country attractiveness for capital inflows, it also might pose a threat to the Montenegrin economy. Namely, according to Edwards and Magendzo (2001) economic growth in dollarized economies might be adversely affected by these countries difficulties in accommodating external disturbances, such as major term of trade and capital flows shocks.

Montenegro, as highly integrated into the regional and global trends, was severely hit by the global financial crisis (GFC). Due to negative trends in the international 
capital markets and lower interest of foreign investors GFC caused a decline in the capital inflows. Although, capital inflows have been the main driving force of the economy during last decade, they pose Montenegro highly dependent on the foreign investors` willingness to invest, but also the on indebtedness of the domestic sectors. Namely, given that Montenegrin banking sector is around $90 \%$ foreign owned, banks and their borrowings, are also influenced by the financial position of their parent banks. Thus, capital flows present important transmission channel from international environment to Montenegro, which is directly in connection with the level of general economic activity and situation in financial markets CBM (2012). Furthermore, given that the external debt is high, it is evident that the Montenegrin economy's potential vulnerability lies here. Due to the increased risks of vulnerable capital inflows on the one hand, and country's euroisation together with the inability to impose controls on the free flow of capital on the other hand, our intention in this paper is to assess the effects of both external and country-specific shocks on capital flows dynamics and derive some policy recommendations.

Analysing capital flows in Montenegro, we may note that foreign direct investment are more pronounced and important. It is expected that investment in more productive assets such as FDIs are more important that investment in securities for a developing country like Montenegro. Namely, for portfolio investment it is important that country has developed money and capital market, which is not a Montenegrin case. The movements of portfolio investments in Montenegro are characterized by an increase in liabilities of banks, government and other sectors in economy based on borrowings. The movements in this account significantly changed over period of twelve years. The total inflow from portfolio investments in Montenegro is largely driven by investments in domestic securities which are primarily related to the government borrowing trough the Eurobonds issues and their selling at the international market. In contrast to portfolio investment, inflows of FDI have amounted to large numbers over observed period.

According to the best of our knowledge, no research has been done on examining capital flow in euroized economy, such as Montenegrin. Hence, this paper addresses the following research questions: (1) Whether global shocks are dominant factors that influence on capital flows in euroized economy; (2) whether in fully euroized economy, domestic shocks have any impact on capital flows and (3) how that impact differ for foreign direct investments and portfolio investments.

The remainder paper is organized as follows: In Section 2 the relevant empirical literature is briefly analysed. In the next Section the methodology for modelling determinants of capital flows is explored. The data used in the estimation, as well as the empirical analysis are introduced in the section 4 . The model's results are discussed in Section 5. Section 6 concludes the paper. 


\section{Literature review}

In the empirical literature, there are two different approaches: one that identifies aggregate shocks and other which makes a difference between internal and external shocks. The literature on the determinants of capital flows to emerging markets has, in general, focused on two sets of indicators: external (push) and internal (pull). Push or external indicators, refer to macroeconomic indicators of developed countries which have influence on the capital flows` supply to developing countries.

Empirical literature on capital flows suggests that the main push determinants of capital flows are output, risk and interest rates. Although positive economic developments in creditor countries are expected to influence the supply of capital flows to developing recipient countries, the evidence for the role of foreign output in determining capital flows is mixed across various studies. Namely, there are studies, like Calvo (1999), which suggest that more developed countries during economic downturns, are likely to invest more into developing countries. Thus, there is a negative substitution between economic growth in creditor economy and capital flows to the recipient economy. Ratha and Dasgupta (1999) find no statistically significant relationship between foreign output growth and FDI inflows, while Ahmed and Zlate (2014) do not find a significant impact of developed economy growth on portfolio flows in 12 emerging market economies. Albuquerque et al. (2005) find evidence for a negative impact of global growth on FDI flows to developing countries. Lastly, findings of studies which investigate determinants of banking flows are also mixed. Namely, Bruno and Shin (2013) find a negative impact of foreign growth on banking inflows, while Jeanneau and Micu (2002) find a positive impact.

The level of foreign risk is also expected to influence capital flows. In an environment of perceived low global risks, catching-up economies, such as Montenegro, had more favourable access to external funding than other countries, as capital flowed towards investment in higher-returns. However, in times of high risk aversion foreign investors typically redirect their funds toward safer destinations and into safer and more liquid assets (Jevčák et al., 2010; Fratzscher, 2012, Ahmed and Zlate, 2014). Milesi-Ferretti and Tille (2011) argue that the main feature of the collapse in capital flows to emerging markets during the current crisis has been a shock to risk aversion, as investors' confidence fell abruptly amidst concerns about the quality of financial assets and the solvency of prominent banks.

The significance of interest rates as one of the key determinants of international capital flows has been proved empirically (Calvo, 1999; Gibson and Tsakalotos, 2004; Hadiwibowo and Komatsu, 2011).

Pull or domestic indicators refer to developments of developing country (for example, domestic economic growth, interest rates, some institutional factors, etc.) 
hosting the investment and they are expected to affect the demand for capital flows. While analysing the significance of domestic output in determining capital flows, many studies confirms the positive relations between these two variables. Namely, the countries with a relatively high GDP growth rates should attract more capital flows since the investors would prefer to invest in the country with positive growth indicators (Kalemli-Ozcan et al. 2006; Forbes and Warnock, 2012). However, it does not necessarily mean that the countries with the decline in output would remain unattractive to foreign investments. On the contrary, if the country is in the recession that could lead to decrease in asset prices and an increase in marginal productivity of capital and therefore, those countries might attract more investors. Because of this ambiguity, the effects of domestic output shock would be tested empirically with a special interest in the following sections.

As summarized by De Vita and Kyaw (2008) early studies provide a strong support to the argument that push factors, US interest rates and global cyclical conditions, play a more important role in determining capital flows to developing countries, while later studies have generally failed to confirm this relationship, thus leaving the debate on the determinants of capital flows to developing countries unsolved.

Applying VAR methodologies to examine the relative influences of foreign and domestic income growth on the capital accounts of six countries that have recently joined the European Union, Hegerty (2009) reports divided results. Namely, three countries: Bulgaria, the Czech Republic, and Lithuania are influenced more strongly by foreign shocks, while other three countries: Latvia, Estonia, and Romania show more of a response to domestic shock. Jevčák et al. (2010) analyse capital flows to the new EU Member States from Central and Eastern Europe and provide evidence that external determinants have been important in explaining capital flows to these countries. At the same time, they reveal that the ability of these countries to attract foreign capital has been also influenced by domestic economic and financial conditions and policies. Similar findings have been presented by Atoyan et al. (2012). Namely, estimating the reduced-form equation for capital inflows by OLS using annual data for 2000-07 for a panel of 19 emerging European countries, they provide evidence that push factors (low returns in flow-originating countries), rather than pull factors (high returns in flow-destination countries), drove most of the private capital flows to emerging Europe. Fratzscher (2012), employing a factor model coupled with a dataset of high-frequency portfolio capital flows to 50 economies, confirms also that push factors are more prominent overall as a driver of capital flows for many countries in 2005-08, as well as in particular during the financial crisis. However, in the recovery phases he notes that these factors become less prominent, whereas pull factors dominate in explaining capital flows, in particular for countries in Emerging Asia and Latin America.

In contracts to other studies, De Vita and Kyaw (2008) and Globan (2014) take into account the temporal dynamics of capital flow determinants, given that push and 
pull factors might change over different time periods for various reasons. Namely, they apply a structural vector autoregression model which aims to extract components of capital inflows that are influenced by domestic and foreign shocks separately, and at the same time allows a temporal examination of the impact of certain events, such as global financial crisis or quantitative easing, on capital inflow determinants. Furthermore, as noted by Raghavan et al. (2012) the SVAR methodology is quite flexible as it can accommodate various relationships among macroeconomic variables inferred from economic theories and stylised facts. Those disaggregate analysis between external and domestic factors would imply some important policy implications. Namely, if capital flows of recipient country react mainly to external factors, these countries are vulnerable, even though the domestic policymakers maintain macroeconomic stability. By contrast, if capital flows are predominantly driven by domestic factors, policymakers are better able to affect them.

Finally, most empirical literature related to the Western Balkans examined the transmission of external shocks on domestic GDP and inflation (Dumičić et al., 2015; Jovičić and Kunovac, 2017), some of them focus on the structure of capital flows and exchange rate (Bukovšak, 2017). Moreover, in a broader sense, our analysis might be linked to other strands of existing empirical research (such as Dumičić, 2017, Kunovac et al., 2018), but to the best of authors' knowledge, no similar research has been performed for Montenegro.

\section{Methodology}

As one of the main tools in multivariate data analysis, vector autoregressive models (VAR) have become very popular as an instrument of econometric modelling. Their main characteristic is that all the variables in the VAR model are endogenous and explained solely by their own movements in the past, i.e. by history. On the other side, structural vector autoregressive models (SVAR), which is an extended of the former, allow more explicit modelling of contemporaneous interdependence between endogenous variables. Even though numerous empirical studies which analyse shock impacts between variables in the model used VAR model as an econometric tool, recently many authors have been exploiting SVAR model (Canova, 2005; Mackowiak, 2007; Culha, 2006, Gimet, 2007; Allegret and Sand, 2009; De Vita and Kyaw, 2008; Globan, 2014; Dumičić et al., 2015; Bukovšak et al., 2017). One of the main reasons is the fact that SVAR models take economic theory more into account in identifying the shocks; hence, they produce a better interpretation of results. In fact, SVAR models were introduced in response to criticism about the use of non-restricted VAR models.

To assess determinants of capital flows in Montenegro, the SVAR model is applied. As previously discussed, due to specific characteristics of Montenegrin economy as 
a small, open and euroized, on one hand, and large amount of foreign capital that the country has received in the last years, on other hand, we distinguish between two separate shocks that determine the movements of capital flows - external/ foreign and internal/domestic. In order to measure external and internal shocks on capital flows, we follow the discussion as in Dumičić et al. (2015), Globan (2014) and De Vita and Kyaw (2008).

As already stated in previous section, numerous studies make a difference between external/push and internal/pull factors. External factors are outside the control of Montenegro. Given the significance of integration with the EU and the fact that euro area countries together are the Montenegrin biggest trade partners (together with Serbia), euro area macroeconomic and financial conditions are appropriate proxies for the external environment, especially regarding the opportunity costs of foreign investments. Financing conditions, especially the analysis of interest rates in euro area is relevant for capital flows in Montenegro. Firstly, higher interest rates in the euro area should discourage international investors. Namely, higher interest rates in the euro area could be a sign of a restricting monetary policy, causing less available liquidity for international investments (Globan, 2014). On the other side, lower interest rates in the euro area would encourage investors to search for higher yields outside the euro area.

As mentioned in the previous section, the level of foreign risk is expected to influence capital flows. In an environment of perceived low global risks, catchingup economies, such as Montenegro, had more favourable access to external funding than other countries, as capital flowed towards investment in higher-returns. As suggested in the previous section, pull factors will be also considered in our analysis. Following economic theory, it could be expected to include the interest rates in the model as a valid monetary indicator that could influence on attracting capital flows into Montenegrin banking sector. However, due to the fact that the monetary policy framework in Montenegro does not rely on the interest rate channel since Montenegro is fully euroized, we created a proxy variable choosing a more relevant measure of monetary policy (a similar approach were taken by Ljubaj, 2012 and Bukovšak et al., 2017). Namely, due to specificities of the Montenegrin economy, the central bank uses the reserve requirements instrument as a primary instrument of the monetary policy. With this instrument, central bank primarily affects banking system liquidity and banks' lending activity, indirectly affecting the process of money multiplication in the economy. Its increase indicates monetary tightening, while its decline points to monetary loosening as it leaves banks with more funds. Thus, in our model we considered the introduction of the monetary policy indicator, which was defined as a ratio between required reserves and total assets of the banking sector. However, we concluded that in our further analysis, that indicator might be redundant and additionally due to same unfavourable statistical properties, we excluded it from the model. 
Besides foreign risk, the domestic risk sentiments might play important role in determining how international investors will behave. Therefore, in times of lower risk perception, we expect larger sum, instead of sums of capital flows, bearing in mind that investors take into account some level of safety for their investments. Interest rates in Montenegro are higher compared to interest rates in the euro area, mainly due to the higher country risk. That is the reason why the domestic risk has been proxied by the spread between average Montenegrin and euro area long term cost of borrowings.

To sum up, the capital flows are expected to be influenced by shocks of five main variables (shocks), which can be noted as:

$$
C F_{t}=f\left({ }_{f} u_{t}^{\text {gdp }},{ }_{f} u_{t}^{\text {risk }},{ }_{f} u_{t}^{i r},{ }_{d} u_{t}^{\text {gdp }},{ }_{d} u_{t}^{\text {risk }},{ }_{d} u_{t}^{c f}\right)
$$

Where capital inflows $\left(C F_{t}\right)$ are a function of different shocks (foreign output ${ }_{f} u_{t}^{g d p}$, foreign risk ${ }_{f} u_{t}^{r i s k}$, foreign interest rate ${ }_{f} u_{t}^{i r}$, domestic output ${ }_{d} u_{t}^{g d p}$ and domestic risk ${ }_{d} u_{t}^{r i s k}$ ), where prefix $f$ denotes foreign shocks, whereas prefix $d$ denotes domestic shocks. Here we also include the unknown shocks to capital flows ${ }_{d} u_{t}^{c f}$. We estimated two models. The first model where we analysed foreign direct investments (FDI) as a component of CFs, and the second model with the portfolio investments (PI).

Since the shocks in equation (1) are unobservable, additional identifying assumptions are necessary to uncover underlying structural shocks from the observed data. Thus, we consider a six-variable VAR model to investigate the role of various factors in developments of capital flows (FDI and PI, separately).

Structural representation of VAR model is given with (Lutkepohl, 2011):

$$
A y_{t}=A_{1}^{*} y_{t-1}+A_{2}^{*} y_{t-2}+\ldots+A_{1}^{*} y_{t-p}+B u_{t}
$$

Where $A$ and $A_{i}^{*}$ are structural coefficients. $A$ is the matrix of contemporaneous influence between the variables, $y_{t}$ is a $(n \times 1)$ vector of the endogenous variables $y_{t}=\left(g d p_{t}^{f}, r i s k_{t}^{f}, i r_{t}^{f}, g d p_{t}^{d}, r i s k_{t}^{d}, c f_{t}\right)$. The variables are foreign GDP, foreign risk, foreign interest rate, domestic GDP, domestic risk and one component of capital flows, respectively. $A_{i}^{*}$ is a $(n \times n)$ matrix of lag-length, which represents impulseresponse functions of the shocks to the element $y_{t}, B$ is a $(n \times n)$ matrix that measures the linear relations between structural shocks and those in the reduced form, $u_{t}$ is a $(n \times 1)$ vector of structural shocks. It is important to note that structural shocks are uncorrelated and identically normally distributed.

In order to estimate SVAR model, a reduced form representation is needed:

$$
y_{t}=A_{1} y_{t-1}+\ldots+A_{2} y_{t-p}+\varepsilon_{t}
$$


Where $A_{i}=A^{-1} A_{i}^{*}$ and the reduced form error structure $\varepsilon_{t}=A^{-1} B u_{t}$. Vector $\varepsilon_{t}$ is a $n \times 1$ vector of shocks in reduced form, which are contemporaneously correlated with each other. The relation between structural shocks and reduced form shocks is $A \varepsilon_{t}=B u_{t}$ and reduced form error structure is given with by:

$$
\varepsilon_{t}=A^{-1} B u_{t}=S u_{t}
$$

where $E\left(\varepsilon_{t} \varepsilon_{t}^{\prime}\right)=\Sigma_{\varepsilon}=A^{-1} B B^{\prime} A^{-1^{\prime}}=S S^{\prime}$ where $S=A^{-1} B$.

SVAR estimation uses estimates $\hat{\Sigma}_{\varepsilon}$ obtained from the reduced for VAR, the shortrun covariance relationship and any restrictions in equation (4), and long-run restriction on the accumulated impulse responses (the case we will explain below), to identify and estimate the model. The main challenge in SVAR estimation is that are only $n(n+1) / 2$ moments in $\hat{\Sigma}_{\varepsilon}$ and more than $n(n+1) / 2$ elements in A and B, or in $\mathrm{S}$ matrixes so that those matrices are not identified unless additional restrictions are provided.

Prior knowledge and theory normally suggest restrictions on structural matrices. That allows us to identify and estimate the parameters of the SVAR. Here, we specify restrictions on the long-run impulse-responses (more details are given in Rubio-Ramirez et al., 2010).

The identifying restrictions embodied in the relations $A \varepsilon_{t}=B u_{t}$ and $\varepsilon_{t}=S u_{t}$ are commonly related to short-run restrictions. Blanchard and Quah (1989) proposed an alternative identification method using restrictions on the long-run properties of the accumulated impulse responses.

These long-run restrictions can be noted as:

$$
\begin{gathered}
\left(I-A_{1}-A_{2}-\ldots-A_{p}\right)^{-1} \varepsilon_{t}=\psi \varepsilon_{t}=F u_{t} \\
\Sigma_{\varepsilon}=\Psi^{-1} F F^{\prime} \Psi^{-1^{\prime}}
\end{gathered}
$$

where $\left(I-A_{1}-A_{2}-\ldots-A_{p}\right)^{-1}=\psi$ is the long-run multiplier, which may be estimated using the reduced form VAR parameter estimates. The long-run $\mathrm{F}$ model is related to the $\mathrm{S}$ model through $F=\psi S$ and the order condition requires an additional $n(n+$ 1)/2 restrictions.

The long-run restriction model (F) model employs estimates of the moments $\hat{\Sigma}_{\varepsilon}$ along with covariance relationships and restrictions from equation (4) to estimate the $n^{2}$ elements in F. Thus, long-run identifying restrictions are imposed directly on the elements of this F matrix. The constraints are imposed corresponding to some elements of matrix set to zero, assuming that some structural shocks have no contemporaneous effects on some endogenous variables. The restriction $F_{i, j}=$ 0 means that the accumulated response of the $i$-th variable to the $j$-the structural shock is zero in the long-run. 
After estimating SVAR model we conducted variance decomposition analysis. The idea is to compose the total variance of a time series into percentages attributable to each shock. Also, we looked at the forecast error variance decomposition (FEVD) to calculate the fraction of the forecast error variance of endogenous variable that can be attributed to orthogonalised shocks to itself or to other endogenous variables. Afterwards, we used impulse response functions, or IRFs, to measure the effects of a shock to an endogenous variable on itself and on other endogenous variables.

An alternative method of innovation accounting that we use in our analysis is historical decomposition. The idea is to decompose the observed series into the components corresponding to each structural shock. Burbridge and Harrison (1985) propose transforming observed residuals to structural residuals, and then for each observation beyond some point in the estimation sample, computing the contribution of the different accumulated structural shocks to each observed variable.

The following assumptions were used regarding the long run effects of structural shocks:

- Domestic variables have no effect on foreign variables. It is due to the fact that changes in macroeconomic variables in a small open economy, such as Montenegro, could not have an impact on any foreign variable (such as euro area output, EU risk sentiment or interest rates in the euro area).

- There are three external shocks in this model: foreign supply shock (output), foreign risk and foreign monetary shock (interest rates). All other shocks are treated as domestic. External variables are assumed to be affected only by foreign shocks.

- Foreign demand shocks have no long-term impact on the real output in the euro area, while foreign monetary shocks are affected by shocks to the foreign output, risk sentiment shocks as well as shocks to itself.

- With respect to internal shocks, we focus on two variables: country-specific productivity shock measured by domestic GDP and domestic risk.

$$
\left[\begin{array}{cccccc}
a_{11} & 0 & 0 & 0 & 0 & 0 \\
a_{21} & a_{22} & 0 & 0 & 0 & 0 \\
a_{31} & a_{32} & a_{33} & 0 & 0 & 0 \\
a_{41} & a_{42} & a_{43} & a_{44} & 0 & 0 \\
a_{51} & a_{52} & a_{53} & a_{54} & a_{55} & 0 \\
a_{61} & a_{62} & a_{63} & a_{64} & a_{65} & a_{66}
\end{array}\right]\left[\begin{array}{c}
{ }_{f} u_{g d p} \\
{ }_{f} u_{r i s k} \\
{ }_{f} u_{i r} \\
{ }_{d} u_{g d p} \\
{ }_{d} u_{r i s k} \\
{ }_{d} u_{c f}
\end{array}\right]=\left[\begin{array}{c}
{ }_{f} \varepsilon_{g d p} \\
{ }_{f} \varepsilon_{r i s k} \\
{ }_{f} \varepsilon_{i r} \\
{ }_{d} \varepsilon_{g d p} \\
{ }_{d} \varepsilon_{r i s k} \\
{ }_{d} \varepsilon_{c f}
\end{array}\right]
$$

The equation (6) presented in the matrix form summarizes aforementioned assumptions which explain the relationships between shocks and the long run restrictions based on equation (5). 
We are aware that there certainly exist other variables that could influence movements of capital flows, but due to lack of data in Montenegro, the presented model is the best we may produce at this time. Moreover, quite short time series in Montenegro do not allow adding more variables in the model due to lack of degrees of freedom. However, the shocks included in the model are representative with the precise clarifications of foreign and domestic shocks, having in mind the existing empirical literature on this issue (see, e.g. Blanchard and Quah, 1989; Ahmed et al., 1993; Ahmed and Park, 1994; Clarida and Gali 1994; Bayoumi and Eichengreen, 1994; Glick and Rogoff, 1995; Kim, 1996; Ying and Kim, 2001; De Vita and Kyaw, 2008; Globan, 2014).

\section{Empirical data and analysis}

The data used for estimation of our SVAR model are quarterly data, ranging from 2005:1 to 2017:4. Macroeconomic variables used for study of the determinants of capital flows are the following: euro area GDP, euro area risk, euro area interest rates, domestic GDP and domestic risk.

Data for the real output of euro area were taken from Eurostat. We use 12-month EURIBOR to represent euro area interest rate. The European economic policy uncertainty index (composed by Baker et al. (2016)) was used as a proxy for the euro area risk. Data on domestic GDP, capital flows and other indicators were taken from the national central bank and national statistical office. Capital flows are analysed through the movements of inward foreign direct investments, on one side, and inward foreign portfolio investments on the other side. Those two forms of capital flows are modelled separately with other variables. Due to low quality data and some methodological inconsistencies, we excluded other foreign investments from the capital flows.

As theory and practice suggest, business environment is very important for attracting foreign direct investments. Investor would rather invest funds into country where the climate for business is more favorable. Therefore, we included an additional exogenous variable in model with foreign direct flows to measure how significant it is for movement of foreign direct investments. Based on World Bank group annual report, we interpolated yearly series of doing business indicator. It could be an adequate proxy for a measurement of business climate presented through business regulation and the protection of property rights. That index measure aspects of regulation affecting 11 areas of the life of a business. However, the estimated coefficient is not statistically significant (the coefficient equals -0.001631 , and standard error 0.0234).

All the variables, with the exception of interest rate, are seasonally adjusted. We used variables in logarithms were possible (with exception of euro area interest 
rates). The data were tested for the existence of unit roots using the Augmented Dickey-Fuller (ADF) test and Phillips-Perron (PP) unit root test.

The model we discussed earlier is based on the assumption that nearly all variables (with exception of domestic and foreign GDP) in levels are stationary or trendstationary. In Table 1, the results of Augmented-Dickey-Fuller and Phillips-Perron unit root tests are reported. The null hypothesis of a unit root can be rejected at $1 \%$ significance level for the both types of capital flows, and at 5\% significance level for domestic risk. The variables representing foreign risk and the euro area interest rates are trend stationary. Variables that measure GDP in Montenegro and Euro area are non-stationary, I(1). That is why we evaluated two VAR models in levels at an order that minimizes the Akaike Information criterion, with a trend as an exogenous variable. Two series of GDP domestic and foreign, were differentiated. The AIC is minimized at a lag of 3 (Table A3).

Table 1: ADF and PP test statistics

\begin{tabular}{|l|c|c|c|c|}
\hline \multirow{2}{*}{ Variable } & \multicolumn{2}{|c|}{ Augmented Dickey-Fuller (ADF) } & \multicolumn{2}{c|}{ Phillips-Perron (PP) } \\
\cline { 2 - 5 } & With constant & $\begin{array}{c}\text { Constant and } \\
\text { trend }\end{array}$ & With constant & Constant and trend \\
\hline FDI & $-4.899 * *$ & $-4.870^{* *}$ & $-4.941^{* *}$ & $-4.909 * *$ \\
\hline PI & -2.217 & $-8.396^{* *}$ & $-7.567 * *$ & $-8.296^{* *}$ \\
\hline GDP_f & -0.416 & -2.267 & -0.436 & -1.868 \\
\hline RISK_f & $-3.131 *$ & $-4.805^{* *}$ & $-3.097 *$ & $-4.975^{* *}$ \\
\hline IR_f & -1.025 & $-3.789 * *$ & -0.952 & $-3.607 *$ \\
\hline GDP_d & -1.504 & -2.446 & -1.504 & -2.404 \\
\hline RISK_d & $-3.341 *$ & -2.887 & $-2.613 *$ & -2.933 \\
\hline
\end{tabular}

Note: The non-stationarity hypothesis can be rejected at: **1\% significance level; *5\% significance level. The number of lags in each ADF regression has been selected by minimizing Schwartz information criterion

Source: Authors' calculation; Results are exported from Eviews 10 software package

The model diagnostics suggest that the models fulfil the condition on stability and there is no evidence of serial correlation and non-normality of the VAR residuals. Namely, as reported in Appendix (A1 and A2), Autocorrelation LM test suggests that we cannot reject the null hypothesis of no autocorrelation at $5 \%$ significance level. Furthermore, Jarque-Bera test suggests residuals' joint normality.

The coefficients of shocks which were previously introduced in equation 6 (elements from the last row of matrix A) are presented in Table 2. Namely, the first part of the table refers to a model with foreign direct investments, and the second part relate to a model with portfolio investments. In the first model, 
the estimated coefficients for foreign interest rates and domestic GDP are not statistically significant, while other are robust and statistically significant with the theoretically expected signs. In the model for portfolio investments, the shocks measuring foreign risk and domestic GDP are statistically significant while the others are not.

Table 2: Estimated coefficients of foreign and domestic shocks on capital flows from eq. 6

\begin{tabular}{|l|c|c|c|}
\hline \multicolumn{1}{|c|}{ Shocks } & Coefficient & Std. Error & z-Statistic \\
\hline fUgdp & 0.177252 & 0.030980 & $5.721407^{*}$ \\
\hline fUrisk & -0.079372 & 0.023047 & $-3.443889^{*}$ \\
\hline fUir & -0.000384 & 0.021438 & -0.017916 \\
\hline dUgdp & -0.012925 & 0.021394 & -0.604138 \\
\hline dUrisk & -0.097006 & 0.018678 & $-5.193702^{*}$ \\
\hline Ufdi & 0.103172 & 0.010998 & $9.380830^{*}$ \\
\hline fUgdp & 0.077302 & 0.419169 & 0.184418 \\
\hline fUrisk & -2.424714 & 0.336295 & $-7.210086^{*}$ \\
\hline fUir & -0.048655 & 0.224775 & -0.216463 \\
\hline dUgdp & 0.581832 & 0.216558 & $2.686725^{*}$ \\
\hline dUrisk & 0.055618 & 0.207998 & 0.267397 \\
\hline Upi & 1.425419 & 0.147021 & $9.695358^{*}$ \\
\hline
\end{tabular}

Note: * Significant at 1\% level; ** Significant at 5\% level; *** Significant at $10 \%$ level Source: Authors' calculation; Results are exported from Eviews 10 software package

The main empirical results are presented through structural variance decomposition analysis and the impulse response function. Variance decomposition provides evidence how much random innovations or shocks are relatively important for the variation of affecting variables. The results presented in Table 3 show the percentage of the variance of capital flows (foreign direct and portfolio investments, respectively) in Montenegro that is due to each shock, for different time horizons. 
Table 3: Variance decomposition of capital flows

\begin{tabular}{|c|c|c|c|c|c|c|}
\hline Period & $\begin{array}{c}\text { Shock1 } \\
\text { (gdp_f) }\end{array}$ & $\begin{array}{c}\text { Shock2 } \\
\text { (risk_f }\end{array}$ & $\begin{array}{c}\text { Shock3 } \\
\text { (ir_f }\end{array}$ & $\begin{array}{c}\text { Shock4 } \\
\text { (gdp_d) }\end{array}$ & $\begin{array}{c}\text { Shock5 } \\
\text { (risk_d) }\end{array}$ & $\begin{array}{c}\text { Shock6 } \\
\text { (fdi) }\end{array}$ \\
\hline 1 & 2.135255 & 4.506361 & 6.912608 & 0.207971 & 49.91979 & 36.31802 \\
\hline 2 & 12.30606 & 8.892503 & 24.78225 & 0.178897 & 31.50277 & 22.33752 \\
\hline 3 & 10.63187 & 18.67032 & 28.08313 & 1.737240 & 23.80942 & 17.06801 \\
\hline 4 & 14.99567 & 18.19619 & 25.18042 & 1.479104 & 20.45756 & 19.69106 \\
\hline 5 & 12.65585 & 24.76930 & 22.43073 & 2.840230 & 20.17371 & 17.13017 \\
\hline 6 & 12.15849 & 24.22320 & 23.59058 & 3.546287 & 19.45651 & 17.02494 \\
\hline 7 & 15.73498 & 23.38918 & 24.03516 & 3.450709 & 17.80313 & 15.58685 \\
\hline 8 & 16.86955 & 23.98360 & 23.44400 & 3.588776 & 17.36907 & 14.74501 \\
\hline 9 & 16.54791 & 25.08743 & 22.80189 & 3.589823 & 17.60612 & 14.36682 \\
\hline 10 & 16.03429 & 26.46460 & 23.00346 & 3.473561 & 17.05992 & 13.96417 \\
\hline Period & $\begin{array}{l}\text { Shock1 } \\
\text { (gdp_f) }\end{array}$ & $\begin{array}{c}\text { Shock2 } \\
\text { (risk_f }\end{array}$ & $\begin{array}{c}\text { Shock3 } \\
\text { (ir_f) }\end{array}$ & $\begin{array}{c}\text { Shock4 } \\
\text { (gdp_d) }\end{array}$ & $\begin{array}{c}\text { Shock5 } \\
\text { (risk_d) }\end{array}$ & $\begin{array}{c}\text { Shock6 } \\
\text { (pi) }\end{array}$ \\
\hline 1 & 19.51130 & 19.57599 & 1.555872 & 0.213403 & 22.35310 & 36.79033 \\
\hline 2 & 19.08063 & 26.14849 & 2.777653 & 0.865895 & 19.20580 & 31.92152 \\
\hline 3 & 17.55950 & 20.58237 & 5.353071 & 12.01814 & 16.04061 & 28.44631 \\
\hline 4 & 16.67436 & 19.62422 & 5.321750 & 12.78408 & 15.38516 & 30.21043 \\
\hline 5 & 16.85742 & 22.56280 & 5.014822 & 12.18948 & 14.79278 & 28.58270 \\
\hline 6 & 16.61101 & 24.76780 & 5.263553 & 11.70429 & 14.20702 & 27.44632 \\
\hline 7 & 16.03458 & 26.19928 & 5.193636 & 11.59402 & 13.70436 & 27.27414 \\
\hline 8 & 15.89955 & 26.76935 & 5.151258 & 11.46663 & 13.55431 & 27.15890 \\
\hline 9 & 16.12388 & 26.78162 & 5.077539 & 11.49722 & 13.62031 & 26.89943 \\
\hline 10 & 16.44332 & 26.90972 & 5.099929 & 11.36788 & 13.46818 & 26.71097 \\
\hline & & & & & & \\
\hline & & & & & \\
\hline
\end{tabular}

Looking at the results of variance decomposition, we could conclude that the foreign output, foreign interest rates and euro area risk shocks largely explain the variations in foreign direct investments. On the other side, the most variations in portfolio investments are due to foreign risk. If we exclude random innovations of capital flows itself, that also have the large variation, domestic risk and foreign GDP largely explain the variations in portfolio investments. Moreover, the variance 
measures the cumulative fluctuations over different horizons in the forecast error of changes in the capital flows. In other words, FEVD shows the relative importance of each shock in the model. We perform the forecast error variance decomposition of our two main components of capital flows, by different type of shocks, or by domestic and foreign variables. In both models, foreign shocks are more dominant during the period, but the difference between the shocks is larger in model for FDI. The results are reported in Figure 1.

Figure 1: Forecast error variance decomposition
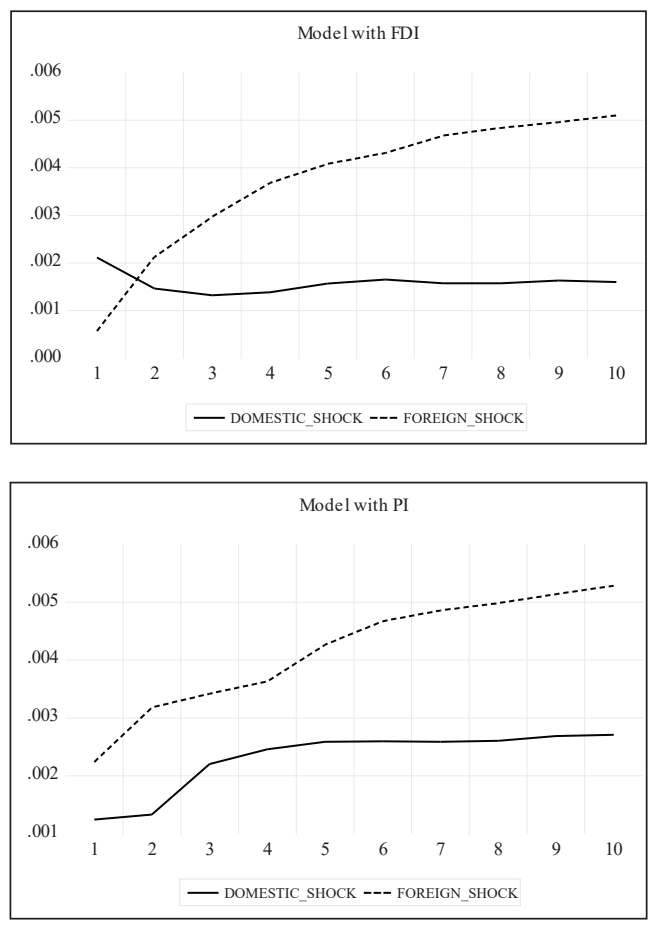

Source: Authors' calculation; Results are exported from Eviews 10 software package

For additional insight into the effects of various shocks on capital flows in Montenegro, we conducted the impulse response analysis. This analysis allows us to follow a one-time shock to an innovation on the endogenous variables. Since our main focus is to trace the shock effect on the two components of capital flows, we present only the impulse responses of capital flows components to our observed shocks. The impulse-response functions have been estimated over the ten-quarter horizon and the results are reported in Figure 2. 
Figure 2: Impulse responses of capital flows components on foreign and domestic shocks

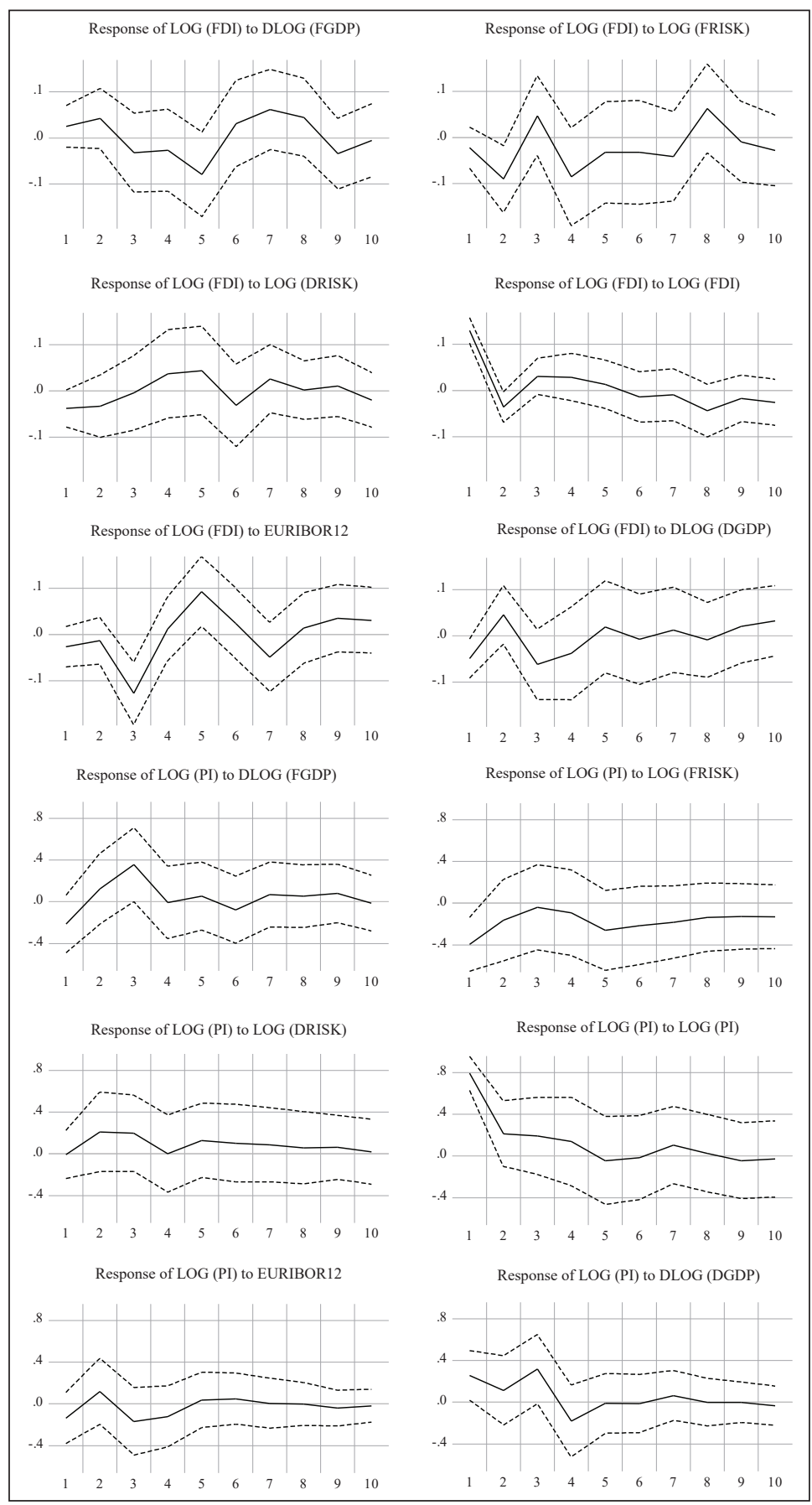

Source: Authors' calculation; Results are exported from Eviews 10 software package 
Figure 2 shows impulse responses of Montenegrin capital account to foreign and domestic shocks. The figure suggests that capital flows appear to respond more intensively to foreign shocks. On the other hand, the influence of domestic shocks on capital flows, in general, is very mild during observed period. When comparing the impulse responses of foreign direct investments with impulse responses of portfolio investments, the first seems to be stronger in intensity with more pronounced volatility. However, it is important to note that there is no strong statistical evidence that the responses are statistically different from zero except at the 1 st period and not for all variables.

Since, previous analysis is not so informative in terms of temporal dynamics and time-varying significance of the two extracted components for capital flow variation, historical decomposition analysis is employed. Namely, we use the historical decomposition from a structural vector autoregression model to examine the temporal dynamics of capital flow determinants and extract components of capital inflows in Montenegro, which are influenced by domestic and foreign shocks separately.

Figure 3: Historical Decomposition of Capital Flows using Structural VAR Weights

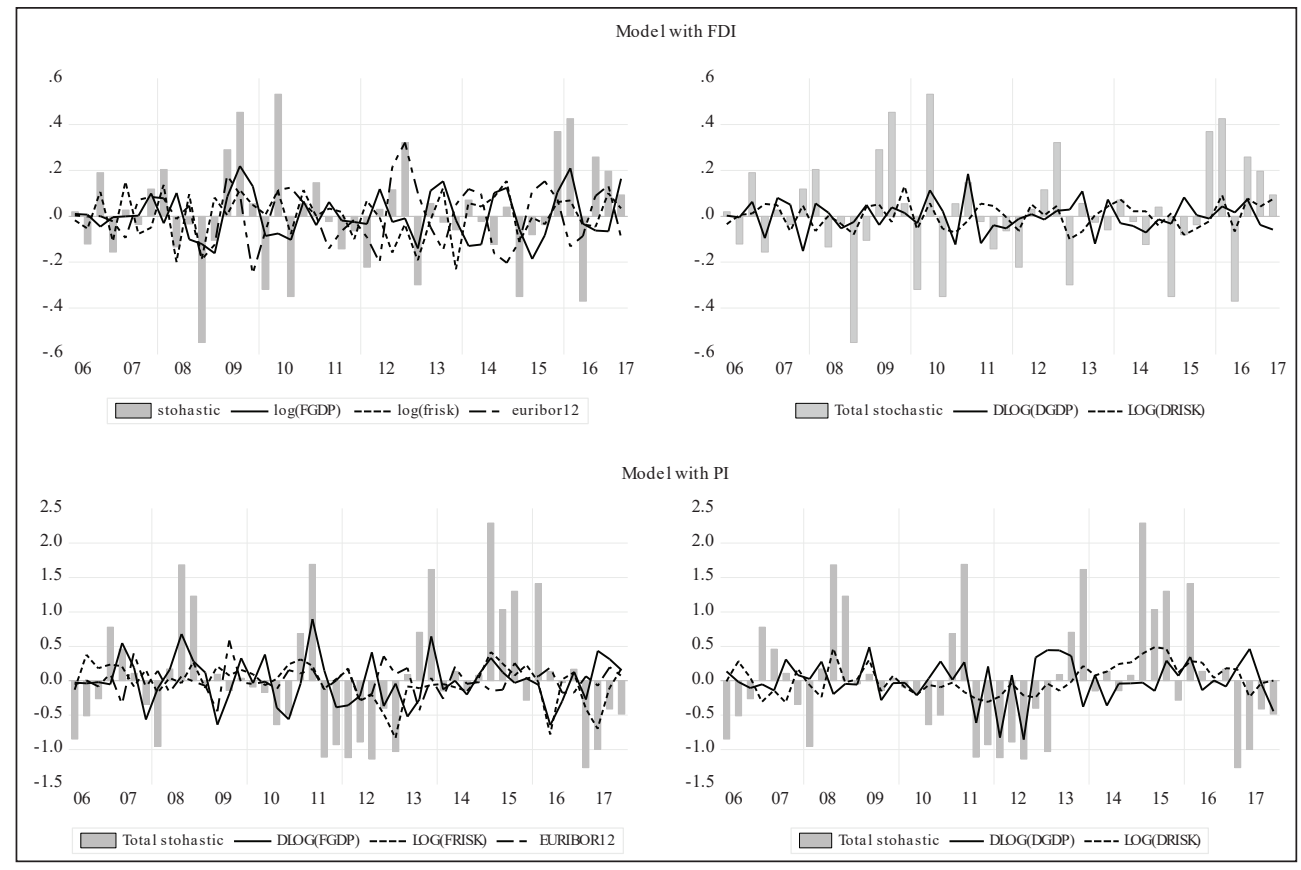

Source: Authors' calculation; Results are exported from Eviews 10 software package

Figure 3 displays the movement of components extracted by the historical decomposition, in relation to the movement of actual capital flows in Montenegro, foreign direct investment flows and portfolio investment flows, separately. As 
previously discussed, the figure confirms that foreign components of foreign direct investment flows mark more intensive movements comparing to the domestic components, while situation with portfolio investments is similar, but much less pronounced.

\section{Results and discussion}

Empirical analysis conducted in the previous section brought some very interesting results on determinants of capital flows in Montenegrin economy. Namely, based on variance decomposition analysis presented in Table 3, the variations in the FDI flows are dominantly explained by shocks of foreign factors especially in medium-term horizon. The shocks of euro area GDP, risk and foreign interest rates appear to affect variations in the FDI flows especially with longer horizon, as they become more persistent with the time, while foreign interest rate shock seems to have stable influence both in short and long-term horizons. However, domestic shocks modelled in our model seem to have less impact in variations of FDI flows. Namely, domestic GDP explains the least of the variations in FDI flows. On the other side, domestic risk has the strong influence on FDI flows in the short term, but diminishing during the time. Therefore, according to variance decomposition results, domestic shocks have less impact on FDI flows variations. Our results clearly indicate that foreign/push shocks, primarily shocks of foreign interest rate and foreign output, are more dominant across various time horizons and represent the key drivers of FDI flows in Montenegro. When inspecting portfolio investment, it can be noticed that the shocks of foreign GDP and foreign risk affect variations in PI flows in the similar way, as for FDI flows. However, foreign risk has less impact on portfolio investments in the longer horizon, but domestic GDP explain the more variations during the time.

In addition, our results indicate that foreign variables are responsible for a larger proportion of the forecast error variance of the both capital flows, while the domestic variables explain less than $25 \%$ of the FDI and PI flows variance. Furthermore, the share of foreign shocks in the FEVD in the forecast error variance consistently rises 2-3 periods after a shock (Figure 1). In the model with FDI, the foreign variables are more responsible for a larger proportion of the forecast error variance. The same proportion is present but at lower level in the model with portfolio investments. This is a clear indicator that overall capital inflows have been influenced by external factors rather than they have reflected the situation in domestic economies through the analysed period, especially in case of FDI.

In more details, the results of the estimated impulse response functions (Figure 2) indicate that the economic fluctuations in the euro area, which are measured by GDP, have a significant influence on the capital flow fluctuations, but only at the 
beginning of the period. However, this influence of fluctuations of GDP in euro area is not consistent during whole observed period, as its effects change from positive to negative, and is not statistically significant. Furthermore, changes in FDI flows into Montenegro can be appropriately attributed to risk sentiment in the euro area. Namely, our findings are in line with the view that capital flows respond to cycles of excessive risk-taking and risk aversion. As previously discussed in the periods of low global risk environment large capital flows are likely to be directed to emerging profitable countries. In contrast, global increase in risk aversion is likely to have severe effect on these countries. Impulse response function suggests that fluctuations in interest rates in euro area have a significant impact on the capital flows in Montenegro only during first four quarters. Precisely, during first two quarters the increase in Euribor 12 positively affects capital flows, while during third and fourth quarter we may notice opposite influence which is in line with empirical literature. Thus, we may conclude that changes in monetary policy in euro area do not have contemporaneous effect on capital flows.

On the other side, when examining influence of domestic shocks, our results imply that an increase of domestic GDP influences positively the FDI flows but not PI flows, with influence is short term, only in first two quarters. Furthermore, the increase in domestic risk has expected negative influence on both capital flows, however this influence is not so pronounced.

The results based on historical decomposition analyisis confirmed our previous findings that foreign or push factors are dominant determinants of both capital flows in Montenegro, especially FDI. Namely, GDP in euro zone and Euribor have been dominant determinants of FDI flows during whole observed period, while euro zone's risk is becoming increasingly dominant determinants of capital inflows in last two years. Domestic GDP, together with foreign risk and other external factors are most evident determinants of PI flows. This result suggests that the rising influence of push factors, particularly euro area risk, might be connected with the higher volatility of capital inflows, thus making host countries more prone to sudden stop episodes. These findings are in line with Globan`s finding (2014).

Further discussion on the before mentioned results is required, especially in terms of its implication on economic policy. Namely, the procyclicality of capital flows implies a difficult task for economic policymakers in small open euroized economy in maintaining the macroeconomic stability in terms of globalization and financial integration, since the economic authorities have limited instruments to manage the inflow of foreign capital. Lipsky (2010) argues that in the absence of an adequate policy and institutional framework capital inflows can complicate macroeconomic management and create systemic stress. IMF (2013) and Forbes et al. (2013) suggest that emerging markets should focus on increasing the resilience of their financial system to the ebb and flow of global financial conditions including through the adoption of macroprudential measures. Nier et al. (2014) argue that some policy 
buffers, like adequate foreign exchange reserves and fiscal buffers may also help in increasing resilience to large and volatile capital flows.

The results obtained in this analysis have strong implications in terms of conducting economic policy. Namely, the country's euroization, high level of external debt and large debt service requirements render the Montenegrin financial sector vulnerable to a slowdown in capital inflows and call for more prudent fiscal policy, as domestic monetary policy is limited. The soundness of the banking system is necessary to booster the resilience of the economy and promotes private sector-led growth. Given that full euroization limits the ability of the central bank to provide liquidity support to banks, sound macro-prudential policy, with adequate capital and liquidity requirements, might be beneficial. Furthermore, the introduction of capital flow management measures which should be part of macroprudential measures may be useful for euroized/dollarized economies, such as Montenegro. Namely, the significant foreign investment in Montenegrin real estate might have been a way to move funds offshore and avoid capital controls, Montenegro there are no such controls. IMF (2015) propose measures which are both macroprudential and capital flow management measures.

The implementation of an appropriate approach to manage capital flows is likely to require a holistic approach. Some countries, like Montenegro where economic growth is mainly led by investment still needs substantial capital flows. Thus, that holistic approach in managing capital flows should consider the economic priorities of the country and the need for responsible macroprudential and fiscal policies, as well as the institutional characteristics of the country. In times of volatile capital flows, highly accumulated external debt and credit expansions fiscal adjustment and a mix of macroprudential, supervisory, and administrative measures to reduce capital inflows is crucial. Last but not least, policy makers should be committed to design macroeconomic policies aimed at increasing productivity and strengthening institutional infrastructure, which would contribute to sustainable economic growth and stimulate the inflow of foreign capital in the export-oriented sectors of the domestic economy.

\section{Conclusion}

Capital flows in Montenegro has increased dramatically since it regained independence. The question whether capital flows are determined more by foreign or domestic factors has become more important with the recent financial crisis, especially in small open and euroized economy.

In this paper, our focus was to develop an empirical model which will respond to aforementioned question. Thus, by using quarterly data for the period of 2005 to 2017 , we estimated a SVAR model to empirically assess to which extent the 
movements of capital flows in Montenegro have been determined by foreign shocks, across different time horizons. In addition, we investigated whether domestic factors can influence capital flows in Montenegro, given the absence of the monetary policy due to euroization. Using impulse response analysis, on one hand, and variance decomposition, on the other hand, we traced the effects of different shocks to the capital inflows in our SVAR and separated the variation of capital flows into the component shocks. Moreover, we employed historical decomposition analysis to investigate the temporal dynamic effects of the foreign and domestic shocks to capital flows. The conducted analysis is clearly an important empirical contribution to empirical literature.

Our main finding suggests that foreign or push shocks are more important for the movements of capital flows in Montenegro than domestic or pull shocks, especially in case of FDI flows. Namely, the empirical results indicate that the majority of the variations of foreign direct investment flows might be explained by foreign output, euro zone interest rates and euro risk sentiment. The domestic shocks appear to play less significant role across various time horizons, except for the variation of the portfolio investments in case of domestic GDP. The reaction of the capital flows in Montenegro to foreign economic fluctuations, i.e. output, interest rate and risk sentiment is expected primarily due to the significant dependence of Montenegro on the euro area in respect of foreign trade and a high dependence of its financial system. Such dependence on foreign determinants makes the Montenegrin economy highly vulnerable to negative economic fluctuations in the euro area. Therefore, we could conclude that hypotheses defined in the manuscript are confirmed.

At the end, it should be noted that there are some obvious limitations of the analysis. The existing problems with the data set, due to short time series, a lack of some important variables and methodological inconsistency, have been serious limitation in development of the empirical model. Namely, the variations of capital flows in Montenegro that are captured in our model did not catch some other important factors, due to lack of data and the importance of role of parsimony in estimating SVAR model. In principle, the idiosyncratic component of capital flows to Montenegro may also be driven by other factors that only economic, such as institutional factors (political stability, protection of property rights, enforcement of law, financial development, progress in the EU enlargement process, the physical infrastructure, etc.). However, these factors are difficult to measure and hardly change over time, so in our specification, these factors are not explicitly modelled, except for a doingbusiness indicator which appear not statistically significant in our model.

The empirical research conducted in this paper suggests the need for future research. Further work should enable formulation of a model consisting of additional noneconomic variables that might also determine the volatility of capital flows. Better and larger statistical base would be crucial for that analysis. However, the results obtained in this paper would serve as a good base to build upon it. 


\section{References}

Ahmed, S., Zlate, A. (2014) "Capital flows to emerging market economies: A brave new world?", Journal of International Money and Finance, Vol. 48, pp. 221248, doi: 10.1016/j.jimonfin.2014.05.015.

Ahmed, S., Park, J.H. (1994) "Sources of macroeconomic fluctuations in small open economies", Journal of Macroeconomics, Vol.16, No.1, pp.1-36, doi: 10.1016/0164-0704(94)90042-6.

Ahmed, S., Ickes, B.W., Wang, P., Yoo, B.S. (1993) "International business cycles", The American Economic Review, Vol. 83, No. 3, pp. 335-359, http://www.jstor. org/stable/2117522.

Albuquerque, R., Loayza, N., Servén, L. (2005) "World market integration through the lens of foreign direct investors", Journal of International Economics, Vol. 66, No. 2, pp. 267-295, doi: 10.1016/j.jinteco.2004.07.002.

Allegret, J.-P., Sand-Zantman, A. (2009) "Does a Monetary Union protect against external shocks?", Journal of Policy Modeling, Vol. 31, No. 1, pp. 102-118, doi: 10.1016/j.jpolmod.2008.09.002.

Atoyan, R. et al., (2012) "The Pre-Crisis Capital Flow Surge to Emerging Europe: Did Countercyclical Fiscal Policy Make a Difference?", IMF Working Papers, Vol. 12, No. 222, pp. 1-34, doi: 10.5089/9781475510270.001.

Baker, S.R., Bloom, N., Davis, S.J. (2016) "Measuring Economic Policy Uncertainty", The Quarterly Journal of Economics, Vol. 131, No. 4, pp. 15931636, doi: 10.1093/qje/qjw024.

Bayoumi, T., Eichengreen, B. (1994) "Macroeconomic Adjustment Under Bretton Woods and the Post-Breton-Woods Float: An Impulse-Response Analysis", The Economic Journal, Vol. 104, No. 425, p. 813, doi: 10.3386/w4169.

Blanchard, O., Quah, D. (1989) "The Dynamic Effects of Aggregate Demand and Supply Disturbances", American Economic Review, American Economic Association, Vol. 79, No. 4, pp. 655-673, http://www.jstor.org/stable/1827924.

Bruno, V., Shin, H.S. (2013) "Capital Flows, Cross-Border Banking and Global Liquidity”, NBER Working Paper, No. 19038, doi: 10.3386/w19038.

Bukovšak, M., Lukinić-Čardić, G., Ranilović, N (2017) "Structure of Capital Flows and Exchange Rate: The Case of Croatia", Working papers W-52, The Croatian National Bank, http://www.hnb.hr/repec/hnb/wpaper/pdf/w-052.pdf.

Calvo, S. (1999) "Capital Flows to Latin America: Is There Evidence of Contagion Effects?” Policy Research Working Papers, doi: 10.1596/1813-9450-1619.

Canova, F. (2005) "The transmission of US shocks to Latin America", Journal of Applied Econometrics, Vol. 20, No. 2, pp. 229-251, doi: 10.1002/jae.837.

Central Bank of Montenegro (CBM) (2012) Financial Stability Report, available at: http://www.cbcg.me/eng/slike_i_fajlovi/fajlovi/fajlovi_publikacije/fin_stabilnost/ financial_stability_report_2012.pdf. 
Clarida, R., Gali, J. (1994) "Sources of real exchange-rate fluctuations: How important are nominal shocks?", Carnegie-Rochester Conference Series on Public Policy, Vol. 41, pp. 1-56, doi: 10.1016/0167-2231(94)00012-3.

Culha, A. (2006) "A Structural VAR Analysis of the Determinants of Capital Flows Into Turkey," Working Papers 0605, Research and Monetary Policy Department, Central Bank of the Republic of Turkey, http://www.tcmb.gov.tr/wps/wcm/ connect/EN/TCMB+EN/ Main+Menu/Publications/Research/Working+Papers/ 2006/06-05.

De Vita, G., Kyaw, K.S. (2008) "Determinants of capital flows to developing countries: a structural VAR analysis", Journal of Economic Studies, Vol. 35, No. 4, pp. 304-322, doi: 10.1108/01443580810895608.

Dumičić, M. (2017). "Effectiveness of Macroprudential Policies in Central and Eastern European Countries". Working papers, Croatian National Bank.

Dumičić, K., Palić, I., Sprajaček, P. (2015) "The role of external shocks in Croatia: block exogeneity SVAR approach. Journal of economic and social development, Vol. 2, No. 1, pp. 44-54, https://hrcak.srce.hr/135727.

Edwards, S., Magendzo, I.I. (2001) "Dollarization, Inflation and Growth", NBER Working Papers 8671, http://www.nber.org/papers/w8671.pdf.

Fabris, N. et al. (2008) Foreign Direct Investments as a Driving Force of Economic Development of Montenegro, Central bank of Montenegro Working Paper, No. 16, http://www.cb-cg.org/eng/slike_i_fajlovi/fajlovi/fajlovi_publikacije/radne_ studije/fdi_driving_force.pdf.

Forbes, K.J., Warnock, F.E. (2012) "Capital flow waves: Surges, stops, flight, and retrenchment", Journal of International Economics, Vol. 88, No. 2, pp. 235251, doi: 10.1016/j.jinteco.2012.03.006.

Forbes, K.J., Fratzscher, M., Straub, R. (2013) "Capital Controls and Macroprudential Measures: What Are They Good For?", SSRN Electronic Journal, doi: 10.2139/ssrn.2364486.

Fratzscher, M. (2012) "Capital flows, push versus pull factors and the global financial crisis", Journal of International Economics, Vol. 88, No. 2, pp. 341356, doi: 10.1016/j.jinteco.2012.05.003.

Gibson, H.D., Tsakalotos, E. (2004) "Capital flows and speculative attacks in prospective EU member states", The Economics of Transition, The European Bank for Reconstruction and Development, Vo. 12, No. 3, pp. 559-586.

Gimet, C. (2007) "L'impact des chocs externes dans les économies du Mercosur: un modèle VAR Structurel", Économie internationale, Vol. 110, pp. 107-136, https://halshs.archives-ouvertes.fr/halshs-00356105.

Glick, R., Rogoff, K. (1995) "Global versus country-specific productivity shocks and the current account", Journal of Monetary Economics, Vol. 35, No. 1, pp. 159-192, doi: 10.1016/0304-3932(94)01181-9. 
Globan, T. (2014) "Financial integration, push factors and volatility of capital flows: evidence from EU new member states", Empirica, Vol. 42, No. 3, pp. 643-672, doi: 10.1007/s10663-014-9270-2.

Hadiwibowo, Y., Komatsu, M. (2011) "Trilemma and macroeconomic policies under different financial structures in Indonesia", Journal of Asian Economics, Vol. 22, No. 4, pp. 302-310, doi: 10.1016/j.asieco.2011.03.002.

Hegerty, S.W. (2009) "Capital flows to transition economies: what is the role of external shocks?", Economics Bulletin, AccessEcon, Vol. 29, No. 2, pp. 1345-1358, http:// www.accessecon.com/Pubs/EB/2009/Volume29/EB-09-V29-I2-P78.pdf.

International Monetary Fund (IMF) (2008) Montenegro - Selected Issues, https:// www.imf.org/external/pubs/ft/scr/2016/cr1680.pdf.

International Monetary Fund (IMF) (2013) Key Aspects of Macroprudential Policy, https://www.imf.org/external/np/pp/eng/2013/061013b.pdf.

International Monetary Fund (IMF) (2015) Measures Which are Both Macroprudential and Capital Flow Management Measures: IMF Approach, http://www.imf.org/external/np/pp/eng/ 2015/041015.pdf.

Jeanneau, S., Micu, M. (2002) "Determinants of International Bank Lending to Emerging Market Countries", SSRN Electronic Journal, doi: 10.2139/ ssrn.846316.

Jovičić, G., Kunovac, D. (2017) "What is Driving Inflation and GDP in a Small European Economy: The Case of Croatia," Working Papers 49, The Croatian National Bank, Croatia.

Kalemli-Ozcan, S., Reshef, A. Sørensen, Bent E, Yosha, O. (2006) "Why Does Capital Flow to Rich States?", CEPR Discussion Papers 5635, C.E.P.R. Discussion Papers, http://www.cepr.org/active/publications/discussion_papers/ dp.php?dpno $=5635$.

Kim, Y. (1996) "Income Effects on the Trade Balance", The Review of Economics and Statistics, Vol. 78, No. 3, pp. 464, doi: 10.2307/2109793.

Kunovac, D., Mandler, M., Scharnagl, M. (2018) "Financial cycles in euro area economies: a cross-country perspective," Working Papers 55, The Croatian National Bank, Croatia.

Lipsky, J. (2010) “The Road Ahead for Central Banks: Meeting New Challenges to Financial Stability", A Speech at a High-Level International Conference on Central Banks and Development of the World Economy: "New Challenges and a Look Ahead", Moscow, Russia, June 18, https://www.imf.org/en/News/ Articles/2015/09/28/04/53/sp061810.

Lutkepohl, H. (2011) Vector autoregressive models, European University Institute, Florence.

Mackowiak, B. (2007) "External shocks, U.S. monetary policy and macroeconomic fluctuations in emerging markets", Journal of Monetary Economics, Vol. 54, No. 8, pp. 2512-2520, doi: 10.1016/j.jmoneco.2007.06.021. 
Milesi-Ferretti, G. M., Tille, C. (2011) The Great Retrenchment: International Capital Flows during the Global Financial Crisis, Working paper 382011, Hong Kong Institute for Monetary Research, http://www.hkimr.org/uploads/ publication/42/ub_full_0_2_304_wp-no-38_2011-final-.pdf.

Nier, E. et al. (2014) "Gross Private Capital Flows to Emerging Markets: Can the Global Financial Cycle Be Tamed?”, IMF Working Papers, Vol. 14, No. 196, p. 1, doi: $10.5089 / 9781498351867.001$.

Raghavan, M., Silvapulle, P., Athanasopoulos, G. (2012) "Structural VAR models for Malaysian monetary policy analysis during the pre- and post-1997 Asian crisis periods", Applied Economics, Vol. 44, No. 29, pp. 3841-3856, doi: 10.1080/00036846.2011.581360.

Ratha, D., Dasgupta, D. (1999) "What Factors Appear to Drive Private Capital Flows to Developing Countries? And How Does Official Lending Respond?", Policy Research Working Papers, doi: 10.1596/1813-9450-2392.

Ying, Y.H., Kim, Y. (2001) "An Empirical Analysis on Capital Flows: The Case of Korea and Mexico", Southern Economic Journal, Vol. 67, pp. 954-968. 


\title{
Kapitalni tokovi u Crnoj Gori: primjena SVAR modela ${ }^{1}$
}

\author{
Milena Lipovina-Božović ${ }^{2}$, Maja Ivanović ${ }^{3}$
}

\begin{abstract}
Sažetak
S globalnom financijskom krizom, sve veća pozornost usmjerena je na analiziranje internih $i$ eksternih faktora koji utječu na tokove kapitala. Naime, globalna financijska kriza pokazala je da veliki i promjenljivi tokovi kapitala mogu biti rizični posebno za mala $i$ otvorena gospodarstva. U radu se osobito analizira ranjivost tokova kapitala $u$ zemlji $s$ ograničenom monetarnom politikom. Usredotočeni smo na Crnu Goru, zemlju koja je jednostrano usvojila euro 2002. godine i ponovno stekla neovisnost 2006. godine. Od tada, Crna Gora je postala vrlo atraktivna za investicije i imala je značajne priljeve stranog kapitala. Stoga, $u$ ovom radu procjenjujemo u kojoj mjeri globalni šokovi mogli biti opasni za tako malu otvorenu ekonomiju. Osim toga, ispitujemo da li i u kojoj mjeri, domaći čimbenici mogu utjecati na tokove kapitala zbog pune euroizacije. Da bismo odgovorili na ova pitanja primijenili smo strukturni vektorski autoregresivni model korištenjem kvartalnih podataka od 2005. do 2017. godine. Rezultati istraživanja pokazuju da uglavnom eksterni faktori, kao što su inozemne kamatne stope i europski rizik, značajno objašnjavaju varijaciju tokova kapitala. Nadalje, domaći čimbenici imaju manju ulogu na kretanje tokova kapitala u Crnoj Gori.
\end{abstract}

Ključne riječi: kapitalni tokovi, eksterni i interni faktori, strane direktne i portfelj investicije, SVAR, Crna Gora

JEL klasifikacija: C32, F21, F32

1 Rezultati istraživanja, tumačenja i zaključci iz ovog rada pripadaju isključivo autorima i ne smiju se pripisati Ekonomskom fakultetu Sveučilišta u Crnoj Gori i Središnjoj banci Crne Gore.

2 Doktorica ekonomskih znanosti, asistentica, Sveučilište u Crnoj Gori, Ekonomski fakultet, Jovana Tomaševića 37, 81000 Podgorica, Crna Gora. Znanstveni interes: makroekonomija, primijenjena ekonometrija, ekonomska statistika i matematički modeli. Tel.: +38220241 138 . Fax: +38220244 588. E-mail:milena@ac.me (osoba za kontakt).

3 Doktorica ekonomskih znanosti; Specijalni savjetnik ravnatelja Odjela za financijsku stabilnost, istraživanje i statistiku, Središnja banka Crne Gore, Bulevar Sv. Petra Cetinjskog br.6, 81000 Podgorica, Crna Gora. Znanstveni interes: makroekonomija, monetarna ekonomija i primijenjena ekonometrija.Tel.: +382 20403 221.E-mail: maja.ivanovic@cbcg. me. 
Milena Lipovina-Božović, Maja Ivanović • Capital flows in Montenegro: SVAR model

\section{Appendices}

Table A1a: VAR residual serial correlation LM test for model with FDI

\begin{tabular}{|c|c|c|c|c|c|c|}
\hline \multicolumn{7}{|c|}{ Sample: 2005Q1 2017Q4 } \\
\hline \multicolumn{7}{|c|}{ Included observations: 44 } \\
\hline Lag & LRE* stat & df & Prob. & Rao F-stat & df & Prob. \\
\hline 1 & 39.23810 & 36 & 0.3268 & 1.085081 & $(36,29.1)$ & 0.4141 \\
\hline 2 & 42.92081 & 36 & 0.1988 & 1.242532 & $(36,29.1)$ & 0.2756 \\
\hline 3 & 38.99916 & 36 & 0.3364 & 1.075294 & $(36,29.1)$ & 0.4240 \\
\hline 4 & 52.18908 & 36 & 0.0596 & 1.699182 & $(36,29.1)$ & 0.0724 \\
\hline 5 & 38.43404 & 36 & 0.3598 & 1.052345 & $(36,29.1)$ & 0.4479 \\
\hline 6 & 48.60971 & 36 & 0.0781 & 1.511872 & $(36,29.1)$ & 0.1274 \\
\hline 7 & 39.22310 & 36 & 0.3274 & 1.084465 & $(36,29.1)$ & 0.4147 \\
\hline 8 & 19.66381 & 36 & 0.9877 & 0.430028 & $(36,29.1)$ & 0.9915 \\
\hline
\end{tabular}

Source: Authors' calculation; Results are exported from Eviews 10 software package

Table A1b: VAR residual serial correlation LM test for model with PI

\begin{tabular}{|c|c|c|c|c|c|c|}
\hline \multicolumn{7}{|c|}{ Sample: 2005Q1 2017Q4 } \\
\hline \multicolumn{7}{|c|}{ Included observations: 47 } \\
\hline Lull hypothesis: No serial correlation at lag h \\
\hline 1 & 31.95547 & 36 & 0.6614 & 0.853887 & $(36,55.5)$ & 0.6894 \\
\hline 2 & 51.30865 & 36 & 0.0571 & 1.586968 & $(36,55.5)$ & 0.0697 \\
\hline 3 & 46.10538 & 36 & 0.1206 & 1.370254 & $(36,55.5)$ & 0.1432 \\
\hline 4 & 28.63627 & 36 & 0.8038 & 0.746677 & $(36,55.5)$ & 0.8230 \\
\hline 5 & 35.69833 & 36 & 0.4828 & 0.980821 & $(36,55.5)$ & 0.5168 \\
\hline 6 & 44.46818 & 36 & 0.1572 & 1.305223 & $(36,55.5)$ & 0.1831 \\
\hline 7 & 32.41753 & 36 & 0.6397 & 0.869205 & $(36,55.5)$ & 0.6688 \\
\hline 8 & 47.79585 & 36 & 0.0903 & 1.438962 & $(36,55.5)$ & 0.1094 \\
\hline
\end{tabular}

Source: Authors' calculation; Results are exported from Eviews 10 software package 
Table A2a: VAR residual normality test for model with FDI

\begin{tabular}{|c|c|c|c|}
\hline Component & Jarque-Bera & df & Prob. \\
\hline 1 & 0.754971 & 2 & 0.6856 \\
\hline 2 & 0.501019 & 2 & 0.7784 \\
\hline 3 & 0.363637 & 2 & 0.8338 \\
\hline 4 & 0.342189 & 2 & 0.8427 \\
\hline 5 & 1.728094 & 2 & 0.4215 \\
\hline 6 & 1.327565 & 2 & 0.5149 \\
\hline Joint & 5.017474 & 12 & 0.9574 \\
\hline
\end{tabular}

Source: Authors' calculation; Results are exported from Eviews 10 software package

Table A2b: VAR residual normality test for model with PI

\begin{tabular}{|c|c|c|c|}
\hline Component & Jarque-Bera & df & Prob. \\
\hline 1 & 0.963931 & 2 & 0.6176 \\
\hline 2 & 7.749243 & 2 & 0.0208 \\
\hline 3 & 0.420033 & 2 & 0.8106 \\
\hline 4 & 0.143075 & 2 & 0.9310 \\
\hline 5 & 2.293968 & 2 & 0.3176 \\
\hline 6 & 2.443723 & 2 & 0.2947 \\
\hline Joint & 14.01397 & 12 & 0.2998 \\
\hline
\end{tabular}

Source: Authors' calculation; Results are exported from Eviews 10 software package

Figure A1: Inverse roots of AR characteristic Polynomial

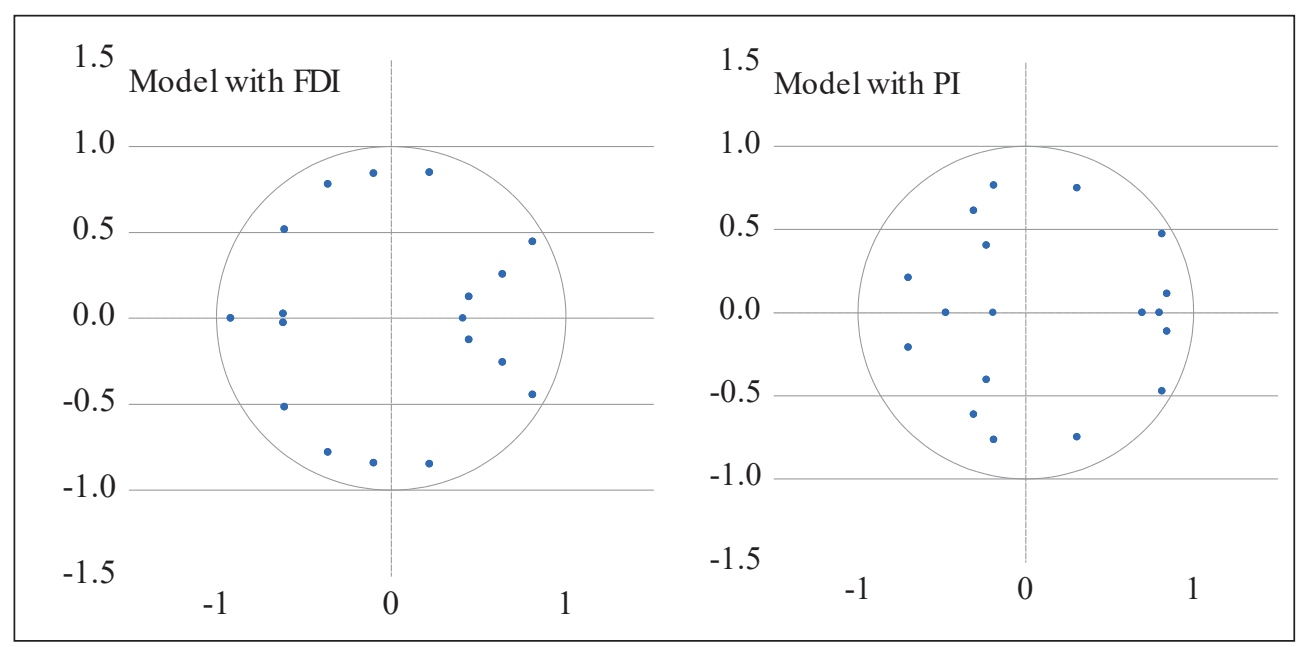

Source: Authors' calculation; Results are exported from Eviews 10 software package 
Milena Lipovina-Božović, Maja Ivanović • Capital flows in Montenegro: SVAR model

Table A3a: VAR lag order selection criteria for FDI model

\begin{tabular}{|c|c|c|c|c|c|c|}
\hline \multicolumn{7}{|c|}{ VAR Lag Order Selection Criteria } \\
\hline \multicolumn{7}{|c|}{$\begin{array}{c}\text { Endogenous variables: DLOG(FGDP) LOG(FRISK) EURIBOR12 DLOG(DGDP) LOG(DRISK) } \\
\text { LOG(FDI) }\end{array}$} \\
\hline \multicolumn{4}{|c|}{ Sample: 2005Q1 2017Q4 } & & & \\
\hline \multicolumn{5}{|c|}{ Included observations: 44} & & \\
\hline Lag & $\log L$ & LR & FPE & AIC & $\mathrm{SC}$ & HQ \\
\hline 0 & 306.6009 & NA & $4.30 \mathrm{e}-13$ & -11.48186 & -9.292172 & -10.66982 \\
\hline 1 & 414.0156 & 141.5922 & $1.92 \mathrm{e}-14$ & -14.72798 & $-11.07850^{*}$ & -13.37458 \\
\hline 2 & 473.0836 & 61.75285 & $9.40 \mathrm{e}-15$ & -15.77653 & -10.66726 & -13.88176 \\
\hline 3 & 547.6788 & $57.64173^{*}$ & $3.30 \mathrm{e}-15^{*}$ & $-17.53085^{*}$ & -10.96179 & $-15.09473 *$ \\
\hline
\end{tabular}

Source: Authors' calculation; Results are exported from Eviews 10 software package

Table A3b: VAR lag order selection criteria for model with PI

\begin{tabular}{|c|c|c|c|c|c|c|}
\hline \multicolumn{7}{|c|}{$\begin{array}{c}\text { Endogenous variables: DLOG(FGDP) LOG(FRISK) EURIBOR12 DLOG(DGDP) LOG(DRISK) } \\
\text { LOG(PI) }\end{array}$} \\
\hline \multicolumn{4}{|c|}{ Sample: 2005Q1 2017Q4 } & & & \\
\hline \multicolumn{5}{|c|}{ Included observations: 47} & & \\
\hline Lag & $\log L$ & LR & FPE & AIC & $\mathrm{SC}$ & HQ \\
\hline 0 & 187.8000 & NA & $6.36 \mathrm{e}-11$ & -6.459574 & -5.042439 & -5.926296 \\
\hline 1 & 343.1593 & 231.3862 & $4.21 \mathrm{e}-13$ & -11.53869 & $-8.704425^{*}$ & -10.47214 \\
\hline 2 & 383.0409 & 49.21559 & $4.26 \mathrm{e}-13$ & -11.70387 & -7.452465 & -10.10404 \\
\hline 3 & 440.8905 & $56.61874 *$ & $2.48 \mathrm{e}-13^{*}$ & $-12.63364 *$ & -6.965100 & $-10.50053^{*}$ \\
\hline
\end{tabular}

Source: Authors' calculation; Results are exported from Eviews 10 software package 